\title{
Yb系モード同期レーザーによる高繰り返し光周波数コム
}

\author{
小林 洋平 \\ 東京大学物性研究所（广277-8581 千葉県柏市柏の葉5-1-5） \\ JST-ERATO, JST-CREST
}

\section{High-Repetition-Rate Optical Frequency Comb by Using Yb-Doped Mode-Locked Lasers}

\author{
Yohei KOBAYASHI \\ The institute for solid state physics, University of Tokyo, 5-1-5 Kashiwanoha, Kashiwa, Chiba 277-8581
} JST-ERATO, JST-CREST

(Received July 21, 2011)

\begin{abstract}
It has passed more than 10 years since an optical-frequency comb was invented. There are some kind of combs such as Ti:sapphire comb and Er:fiber comb, and they have advantages and disadvantages. It is difficult to achieve both good long- and short-term stability. Here we discuss the present status of Ybdoped-laser based optical frequency comb and its prospects. We also discuss about future applications by wavelength expanded frequency combs.
\end{abstract}

Key Words: Optical frequency comb, Mode-locked laser, Yb-fiber laser, High harmonic generation, Precision measurement

1. はじめに

光周波数コムとはどういうものなのか. 分散のない光 共振器で許される縦モード光周波数は $f=m \times c / 2 l(m$ : 自 然数, $c$ : 光速, $l$ : 共振器長) と書けモードスペーシン グは等間隔となるが, 実際のレーザー発振器では屈折率 が波長依存を示すため, 縦モード間隔は不等となる。 と ころがレーザーにモード同期を掛けるとレーザーパルス は極めて正確に等間隔で繰り返される。これは, 広い久 ペクトル内の縦モード間隔が高精度に一致していること を示す。モード同期ではレーザー媒質やミラーによる分 散を打ち消すように非線形分散が加わり縦モード間隔を そろえる働きがあるからである，様々なモード同期の原 理があるが超短パルス発生によく用いられるカーレンズ モード同期の例で考えると，レーザー媒質中でピーク強 度が大きくなるほどカーレンズの働きで共振器の安定状 態になりゲインが大きくなるようにできている。このた めレーザー共振器はより短パルスになろうとする力が働 き, 広い波長域で群速度を一致させようとする。つまり 縦モード間隔が広いスペクトルに渡り等間隔になるので ある。これはレーザー自身が非線形分散を生み出すこと により実現する。もともと共振器内分散で不等間隔で あった縦モードを強制的に等間隔にすると，どこかにひ ずみが生じる。これがいわゆるオフセット周波数 $\left(f_{0}\right)$ で ある。ここまでの考察でモード同期レーザーの $m$ 番目の 縦モード光周波数 $f$ は $f_{\mathrm{rep}}$ を繰り返し周波数とすると $f=f_{0}+m \cdot f_{\text {rep }}$ と書けることがわかる。モモド同期レー ザーの繰り返し周波数はもともと高安定であり制御が簡 単なことから, 規則正しい縦モード間隔を得ることはた やすい. もしオフセット周波数の摇らぎが十分ゆっくり で小さいならば, 縦モード間隔よりも縦モードの線幅は 狭いことも明らかである。つまり，通常の $100 \mathrm{MHz}$ 程度 の繰り返しを持つモード同期レーザーの縦モード線幅は cwレーザーで苦労して作りだされる線幅程度に狭い.

T. W. Hänschらは早くからこのモード同期レーザーの 性質に目をつけ，超短パルスレーザーを使った精密分光 のデモンストレーションを行った ${ }^{1-4)}$. しかしながら実 際にはレーザー共振器は機械的摇らぎやポンプの摇らぎ などによりオフセット周波数は不定となるため, 絶対周 波数を議論するような使い方はできず，80年代 -90 年代 は周波数チェーン方式での光周波数測定が先行してい $た^{5)}$. これは多段の波長変換と光位相同期を組み合わせ 光周波数をRF周波数にまでつなげる装置である.

事態が大きく変わったのはルーセントテクノロジーと バス大学で同時期に開発されたフォトニッククリスタル ファイバを用いた白色光発生の実現による ${ }^{6,7)}$. この発 明により自己参照法と呼ばれる方法でオフセット周波数 を制御することができるようになり，モード同期レー ザーによる光周波数コムは完成する ${ }^{8-11)}$.

初期の光周波数コムは全てチタンサファイアレーザー により実現されたが，数年後Erファイバレーザーによる コムの研究が始まった ${ }^{12-14)}$. Erファイバレーザーコムは 
チタンサファイアレーザーコムにくらベフリーランでの オフセットビート線幅が広い問題があるが，後に位相同 期の帯域を広げることにより狭線幅に出来るようになっ $た^{15,16)}$.

チタンサファイアレーザーコムとErファイバレーザー コムにはそれぞれ長所と短所がある。長所を一言で言う と, 前者は短期安定度, 後者は長期安定度に優れている ということだろう。チタンサファイアレーザーのオフ セットビートはフリーランでkHz〜10 kHz程度の狭い線 幅を持つ。さらに上準位寿命が3マイクロ秒程度なので

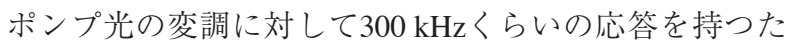
め速いフィードバックループが成り立つ。しかしながら 励起光源として数W〜10 Wの大型グリーンレーザーが 必要なため1日以上の長時間運転に難がある。一方 $\mathrm{Er}$ ファイバコムはLD励起かつオールファイバで自己参照 法まで作りこめるため，長期間にわたりコムを持続する ことが出来る。しかも通信波長帯であるためにコムのデ リバリにも適している。しかしながら, フリーランで広 い線幅を持ち上準位寿命が長いため, ポンプ光の変調に よるフィードバックは $\mathrm{kHz}$ 程度のバンド幅に限られる。 このため狭線幅に制御するためには高い技術を要する。

\section{Ybファイバコム}

第3のコムとして筆者が注目しているのがYb系のコム である. Yb系モード同期レーザーにはファイバと固体 の何種類かあるが, 驚くべきことにYbファイバレー ザーはどのYb系固体レーザーよりも短パルスを発生さ せる ${ }^{17)}$. 超短パルスを発生させるということで夕イトな モード同期による縦モードの短期安定度も期待される。 ファイバレーザーであるため長期安定度に優れる。ま た, 波長領域が1ミクロン帯であり, 多くの光原子時計 の時計レーザーの波長域をカバーする.

特にTable 1に示すように, NISTのシングルイオン時 計で世界最高峰をいく $\mathrm{Hg}^{+}$と $\mathrm{Al}^{+} や$, 香取らが提案した 光格子時計 ${ }^{18)}$ に重要な $\mathrm{Sr}, \mathrm{Yb}$ や $\mathrm{Hg}$ の時計用レーザーの うち大部分は 1 ミクロン帯にある。この波長のマッチン グのよさも Yb系レーザーによる光周波数コムの魅力で ある。

さらにYbファイバレーザーシステムの最も特徵的な 性質として高平均出力化が挙げられる. Ybファイバは 976nmのLDで直接励起できる.さらにダブルクラッド 構造のファイバを使うことができるため，横マルチモー ドのLDで励起できる。 そのため増幅器の励起に用いる

Table 1 Typical clock laser wavelength.

\begin{tabular}{lcc}
\hline & $\begin{array}{l}{ }^{1} \mathrm{~S}_{0}{ }^{-} \mathrm{P}_{0} \\
\text { clock transition) }\end{array}$ & Clock laser \\
\hline $\mathrm{Yb}$ & $578 \mathrm{~nm}$ & $1156 \mathrm{~nm}$ \\
\hline $\mathrm{Sr}$ & $698 \mathrm{~nm}$ & $698 \mathrm{~nm}$ \\
\hline $\mathrm{Hg}$ & $265.6 \mathrm{~nm}$ & $1062 \mathrm{~nm}$ \\
\hline${ }^{199} \mathrm{Hg}^{+}$ & $282 \mathrm{~nm}$ & $1126 \mathrm{~nm}$ \\
\hline${ }^{27} \mathrm{Al}^{+}$ & $267 \mathrm{~nm}$ & $1070 \mathrm{~nm}$ \\
\hline
\end{tabular}

ことのできるLDの平均出力は $200 \mathrm{~W}$ 超える. $\mathrm{Yb}$ フ イバシステムの周辺技術としての励起LDとダブルク ラッドファイバ技術は日進月歩であり，年々高出力化が たやすくなっていくのもレーザーの開発および将来性と しては非常に重要な要素である。また, ファイバ増幅器 は高繰り返しパルス列の増幅に適しており光周波数コム とのマッチングに優れる. 現在までにイエナ大学のグ ループではサブピコ秒でサブkWの平均パワーのシステ ムが構築されるに至っている ${ }^{19)}$. 我々の研究室でもファ イバシステムにおいて200 fsのパルス幅で $80 \mathrm{MHz}$ 繰り返 しにおいて45 Wの増幅ができている。このような高平 均出力のフェムト秒パルス列は後述する波長変換による 光周波数コムのXUVへの波長領域拡大に重要な技術と なる ${ }^{20)}$.

現在までに論文で発表されているYbファイバコムは まだ少ない. 最初のYbファイバベースの光周波数コム はJILAとIMRAアメリカとの共同研究において狭線幅を 達成したとの報告である ${ }^{21)}$ 。後に我々とNISTとの共同 研究で発振器のノイズと縦モードの線幅の議論を行い狭 線幅の実現に必要な知見を得ている22).

Fig. 1に典型的な非線形偏波回転モード同期のYbファ イバ発振器構成と発振スペクトルを示す，Ybファイバ レーザーは波長が1000-1100 nmの範囲であるため, ファイバ内では正常分散領域である。これは異常分散領 域にあるErファイバとは異なり, フリースペースで共振 器の分散補償をしなければならない事を意味する。しか も多くの固体レーザーとは違いファイバ長が $1-2 \mathrm{~m}$ に達 するため大きな群速度分散 (GDD) を補償しなければな らない.メートル級の物質分散を補償するには回折格子 ペアを用いる他なく，このため3次の分散(TOD)につい ては物質分散と同じ符号が付与されてしまう。通常の $100 \mathrm{MHz}$ 程度の発振器において共振器一周で付与される
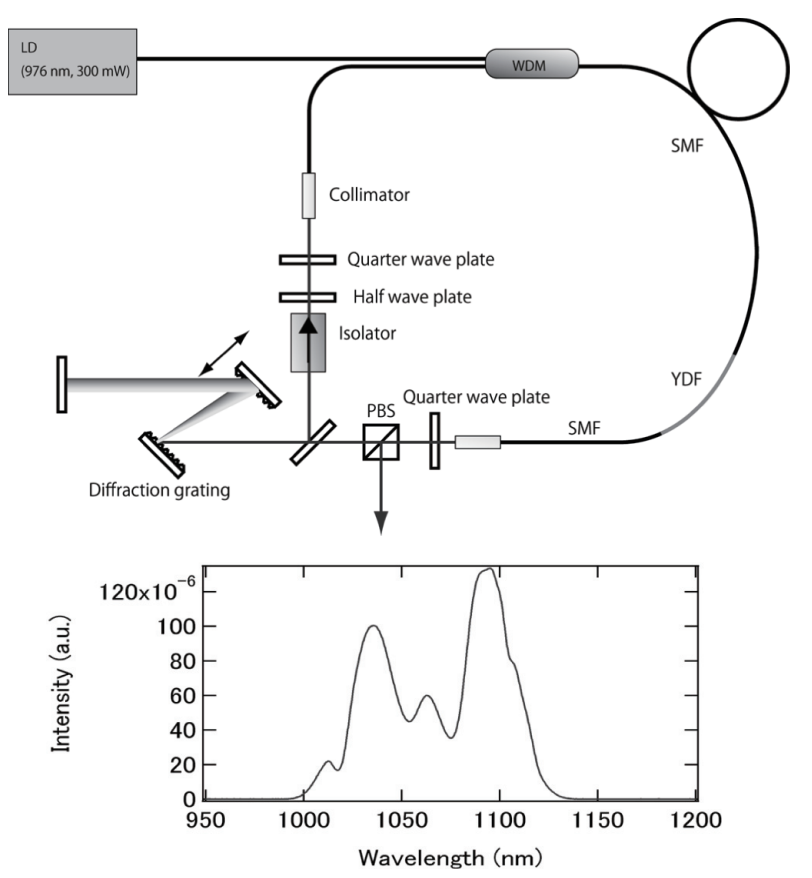

Fig. 1 Experimental setup of mode-locked Yb-fiber oscillator (upper), and its typical spectrum (lower). 
TODは数万〜 10 万 $\mathrm{fs}^{3}$ に及ぶ。 これでは超短パルス発 生は難しい. しかしながら実際に30 fs という超短パルス が発生している(Fig. 2)。良い光周波数コムを実現する には発振器の中で何が起きているかをおおよそ理解する 必要がある。我々は発振器内部の各場所でパルス波形や 分散の付き方がどうなっているかを詳細に調べた。その 結果, 発振器内ではある部分でパルスの時間波形が非対 称になっていて, その時間波形から生み出される自己位 相変調はちょうどTODを打ち消すように働いているこ とを突き止めた23).

これを光周波数コムにするためには一オクターブに広 げる必要があるが，Erシステムとは異なり残念ながら PCFを使わないことにはスペクトルが広がらない。これ も Ybが正常分散であることが原因と思われる。 $100 \mathrm{MHz} \sim 200 \mathrm{MHz}$ 程度の繰り返しであれば1 Wくらい に増幅したものをPCFに入射してあげるとオクターブに 広がる. Fig. 3にこのようにして得られた白色光のスペ クトルと各種時計レーザーの波長を示す.

この白色光のうち，1400 nm成分の第二高調波をと り，700 nmの成分とビートを取ることによりオフセッ 卜を観察する。典型的なフリーラン時のRFスペクトル をFig. 4に示す。このオフセットビートはErファイバの ものよりもチタンサファイアレーザーのそれに近い。フ リーランのオフセットビート線幅が狭いレーザーは制御 性も良く, 短時間安定性の良いチタンサファイアレー ザーのような光周波数コムが実現する可能性がある。才 フセットビートの摇らぎからデジタル位相比較器で誤差

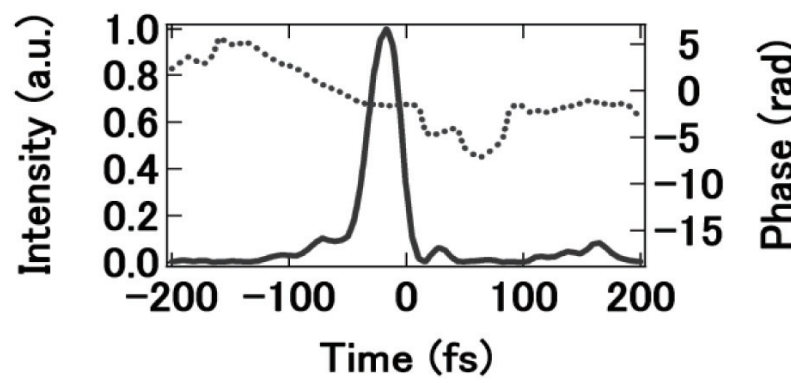

Fig. 2 Temporal profile (solid curve) and phase (dotted curve) of the pulse. The pulse duration is $30 \mathrm{fs}$.

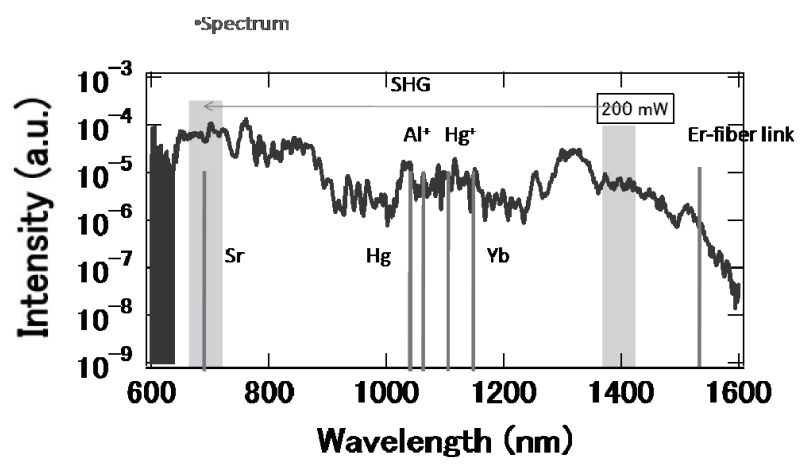

Fig. 3 White continuum from the PCF. The spectrum covers from $650 \mathrm{~nm}$ to $1550 \mathrm{~nm}$. Atoms and ions in graph show the clock-laser wavelengths. Typically $200-\mathrm{mW}$ fundamental light is used for the second harmonic generation (SHG).
信号を作り出し, LDの電流にフィードバックすること により線幅をスペアナの分解能まで制御した。 また，こ れを周波数カウンタで測定したところ10分で11 mHz程 度の摇らぎに抑えることができている。

光周波数測定および光原子時計へ適用するために長時 間安定性の改良を進めている段階である。主にはPCFへ の打ち込みが温度とともに変化してビートのS $/ \mathrm{N}$ 下゙が る問題であり，チタンサファイアレーザーの場合と同じ である。しかしながらシステム全体が励起レーザーも含 めて $60 \mathrm{~cm} \times 45 \mathrm{~cm}$ のボードに収まるため, 温調により 改善されると期待している。 また，現在フリースペース で行っている部分のファイバ化を進めることができれば さらなる安定化が見込める。

\section{3. エンハンスメント共振器によるXUVコム}

光周波数コムには光周波数計測や光原子時計以外にも 様々な応用が考えられるが，コムの波長領域を拡大する と新しい世界が広がる．現在の可視－近赤外領域から短 波長側に拡大するには波長変換が必要である。非線形光 学結晶が使える範囲であれば比較的小型のレーザーでも 波長変換が可能となる。現在の非線形結晶による(位相 整合のとれた) 波長変換の最短波長記録はKBBFを用い た153.4 nmである ${ }^{24)}$ 。これよりも短波長のコムを作るた めにはガスによる高次高調波発生を用いる必要が出てく る。高次高調波発生には $10^{13} \mathrm{~W} / \mathrm{cm}^{2}$ 以上の集光強度が必 要となるが, $100 \mathrm{MHz}$ 程度の繰り返しでこの強度を得る には平均出力の大変大きなレーザーが必要である。100 フェムト秒のパルス幅でも $\mathrm{kW}$ 以上の平均出力を要す る。このようなパワーはファイバレーザーをもってして も現在の技術では到達困難であるが，2005年にJILAと MPQとでそれぞれ開発されたエンハンスメント共振 器 25,26 を用いると共振器内出力がkWを超え, 高繰り返

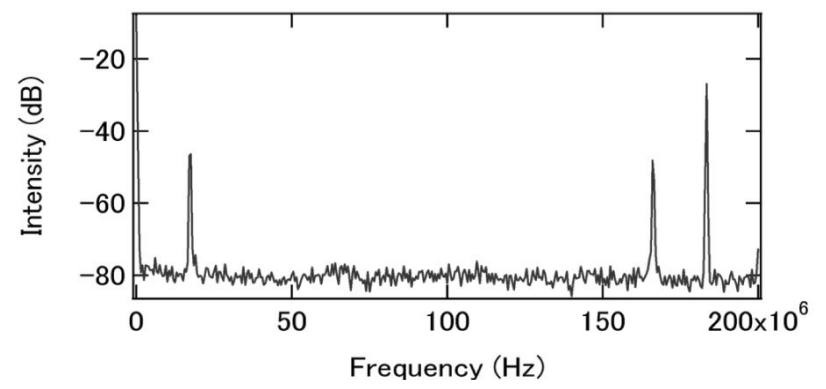

Fig. 4 RF spectrum of the free-running offset beat with the resolution bandwidth of $100 \mathrm{kHz}$. The repetition rate is $180 \mathrm{MHz}$.

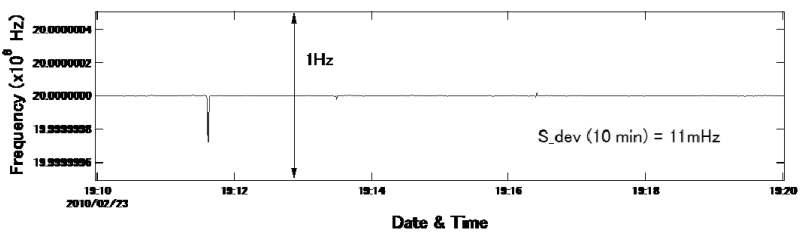

Fig. 5 Offset beat frequency measurement by 1 -s averaged counter for $10 \mathrm{~min}$. The full span is $1 \mathrm{~Hz}$. The standard deviation in 10 minutes is $11 \mathrm{mHz}$. 
しの高次高調波が発生する ${ }^{27,20)}$. 高次高調波のコヒーレ ンスが十分かはまだ議論の余地があるが，このようにし てXUV領域のコムができる。これからXUV精密分光が 立ち上がり，XUV領域の擬 $\mathrm{C} レ$ レー゙ーもできるかもし れない. Fig. 6に得られた高次高調波スペクトルを示 す.

\section{4. 高繰り返し光周波数コムの展望}

通常ファイバコムは50 MHz〜250 MHzまで，チタン サファイアレーザーコムは $100 \mathrm{MHz} \sim 1 \mathrm{GHz}$ モードス ペーシングである。応用の大部分は高繰り返しほど都合 が良い，理由は大きく二つある。ひとつはモードパワー が上がることであり，光周波数測定などの際にcwレー ザーとのビートが強くなるからである。 もうひとつは モードの分離がよりたやすくなるからである。コムの モードナンバーを決めるのが簡単になる他, 回折格子の 分光器でも縦モードが分離できるようになると天文分野 などで威力を発揮する．特に近年アストロコムと呼ばれ る天文用のコム開発が注目されており，この目的には 10 〜 $20 \mathrm{GHz}$ の繰り返しが必要となる ${ }^{28,29)}$. 星の分光をする 際に天文台の分光器の校正を光周波数コムで行うと, い つでもHzレベルの超高精度で校正が行える。この精度 を用いて遠くの星のドップラーシフトを毎日測定するこ とによりその星にどんな惑星があるかが分かる，地球型 惑星を見つけることができれば生命の存在も期待できる のである. 小さい星を見つけるにはそれだけ小さなドッ プラーシフトを観測する必要がある。現在のところ $250 \mathrm{MHz}$ の繰り返しから出発し, フィルタ共振器を何段 か使い10-20 GHzを得る。全てをロックする必要がある ためもともとのレーザーの高繰り返し化ができれば非常 に有用である。ファイバでの高繰り返しには限界がある ため, Yb系固体レーザーでの高繰り返しレーザーシス テムが面白い ${ }^{30-32)}$. 我々はLD励起Yb:KYWで $1.3 \mathrm{GHz}$ の カーレンズモード同期発振器を作り, これを $\mathrm{Yb}$ ファイ バで20 Wにまで増幅した。パルス幅は200 fs程度である

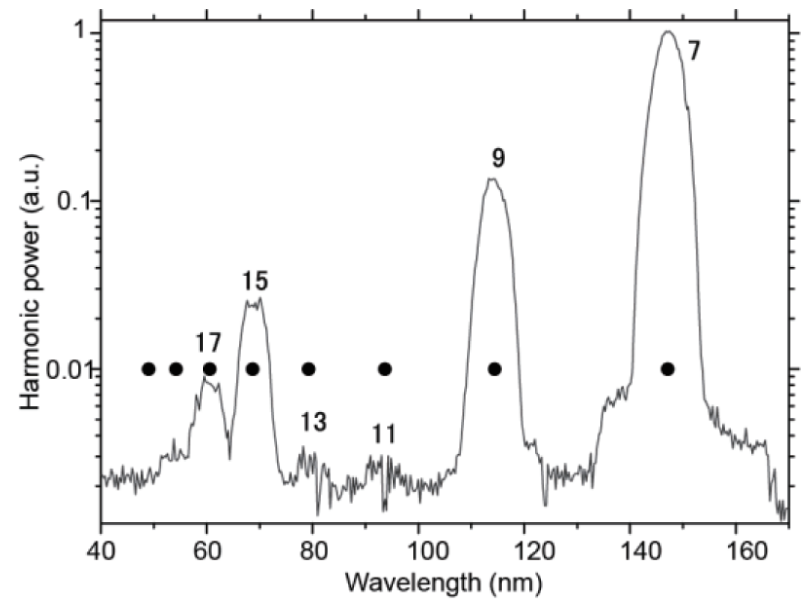

Fig. 6 Obtained spectrum of the high-order harmonics. The coherent XUV light down to $60 \mathrm{~nm}$ is generated. Closed circles represent the wavelengths of each harmonics.

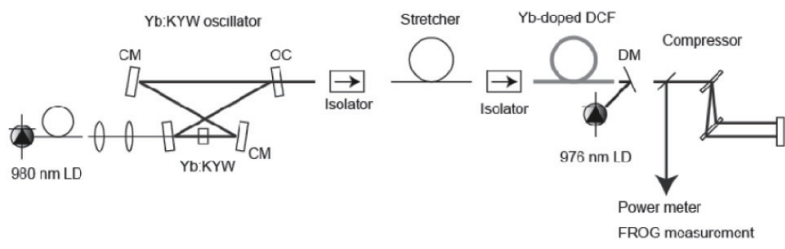

Fig. 7 Experimental setup of the Kerr-lens mode-locked Yb:KYW oscillator and Yb-fiber CPA system. The output power after the compressor is $20 \mathrm{~W}$. DCF, double-clad fiber; LD, laser diode; CM, chirpcompensation mirror; OC, output coupler.

(Fig. 7). この発振器は2 GHz程度まで高繰り返し化が進 んでいる。この繰り返しは次世代エネルギー回収型リニ アックシステムにもちょうど良い.

また，高繰り返しコムによる分子の精密測定も今後注 目すべき分野である，分子の高感度・高精度測定は，呼 気診断など医療分野や環境測定に重要なツールとなるに 違いない ${ }^{33)}$. 特に2台のコムによるフーリエ分光と前述 の外部共振器との組み合わせ測定は高感度かつ高精度測 定が可能である ${ }^{33)}$ ，さらに，分子の基本振動に共鳴した 中赤外コムを用いることができれば数桁の感度改善が見 达める。数年のうちに中赤外コム分光が始まるにちがい ない.

また，より長波長になるとテラヘルツに近づく。フェ ムト秒パルスから変換されるテラヘルツはもともとキャ リア位相 (CEP)が固定されているわけであるから光周波 数コムになっている。高繰り返しテラヘルツのコムとし ての側面を使うような応用もありうる。

\section{謝 辞}

本研究開発の一部はJST-ERATO, JST-CREST, 文部科 学省「光・量子科学研究拠点形成に向けた基盤技術開 発 最先端の光の創成を目指したネットワーク研究拠点 プログラム」拉よび最先端研究基盤事業の支援による.

\section{参考文献}

1) R. Teets, J. Eckstein, and T. W. Hansch: Phys. Rev. Lett. 38 (1977) 760.

2) J. N. Eckstein, A. I. Ferguson, and T. W. Hansch: J. Opt. Soc. Am. 68 (1978) 646

3) J. N. Eckstein, A. I. Ferguson, and T. W. Hansch: Phys. Rev. Lett. 40 (1978) 847.

4) T. W. Hansch and N. C. Wong: Metrologia 16 (1980) 101.

5) H. Schnatz, B. Lipphardt, J. Helmcke, F. Riehle, and G. Zinner: Phys. Rev. Lett. 76 (1996) 18.

6) J. K. Ranka, R. S. Windeler, and A. J. Stentz: Opt. Lett. 25 (2000) 25.

7) J. K. Ranka, R. S. Windeler, and A. J. Stentz: Opt. Lett. 25 (2000) 796.

8) S. A. Diddams, D. J. Jones, L. S. Ma, S. T. Cundiff, and J. L. Hall: Opt. Lett. 25 (2000) 186.

9) S. A. Diddams, D. J. Jones, J. Ye, S. T.Cundiff, J. L. Hall, J. K. Ranka, R. S. Windeler, R. Holzwarth, T. Udem, and T. W. Hansch: Phys. Rev. Lett. 84 (2000) 5102.

10) D. J. Jones, S. A. Diddams, J. K. Ranka, A.Stentz, R. S. Windeler, J. L. Hall, and S. T. Cundiff: Science 288 (2000) 635.

11) R. Holzwarth, T. Udem, T. W. Hansch, J. C. Knight, W. J. 
Wadsworth, and P. S. J. Russell: Phys. Rev. Lett. 85 (2000) 2264.

12) F. Tauser, A. Leitenstorfer, and W. Zinth: Opt. Express 11 (2003) 594.

13) B. R. Washburn, S. A. Diddams, N. R. Newbury, J. W. Nicholson, M. F. Yan, and C. G. Jorgensen: Opt. Lett. 29 (2004) 250.

14) T. R. Schibli, K. Minoshima, F. L. Hong, H. Inaba, A. Onae, H. Matsumoto, I. Hartl, and M. E. Fermann: Opt. Lett. 29 (2004) 2467.

15) W. C. Swann, J. J. McFerran, I. Coddington, N. R. Newbury, I. Hartl, M. E. Fermann, P. S. Westbrook, J. W. Nicholson, K. S. Feder, C. Langrock, and M. M. Fejer: Opt. Lett. 31 (2006) 3046.

16) Y. Nakajima, H. Inaba, K. Hosaka, K. Minoshima, A. Onae, M. Yasuda, T. Kohno, S. Kawato, T. Kobayashi, T. Katsuyama, and F. Hong: Opt. Express 18 (2010) 1667.

17) X. Zhou, D. Yoshitomi, Y. Kobayashi, and K. Torizuka: Opt. Express 16 (2008) 7055.

18) M. Takamoto, F.-L. Hong, R. Higashi, and H. Katori: Nature $\mathbf{4 3 5}$ (2005) 321.

19) T. Eidam, S. Hanf, E. Seise, T. V. Andersen, T. Gabler, C. Wirth, T. Schreiber, J. Limpert, and A. Tünnermann: Opt. Lett. 35 (2010) 94.

20) A. Ozawa and Y. Kobayashi: in CLEO:2011 - Laser Applications to Photonic Applications, OSA Technical Digest (CD) (Optical Society of America, 2011), paper CThB4.

21) T. R. Schibli, I. Hartl, D. C. Yost, M. J. Martin, A. Marcinkevicius,
M. E. Fermann, and J. Ye: Nature Photon. 2 (2008) 355.

22) L. Nugent-Glandorf, T. A. Johnson, Y. Kobayashi, and S. A. Diddams: Opt. Lett. 36 (2011) 1578.

23) N. Kuse, Y. Nomura, A. Ozawa, M. Kuwata-Gonokami, S. Watanabe, and Y. Kobayashi: Opt. Lett. 35 (2010) 3868.

24) Y. Nomura, Y. Ito, A. Ozawa, X.-Y. Wang, C.-T. Chen, S. Shin, S. Watanabe, and Y. Kobayashi: Opt. Lett. 36 (2011) 1758.

25) C. Gohle, T. Udem, M. Herrmann, J. Rauschenberger, R. Holzwarth, H. A. Schuessler, F. Krausz, and T. W. Hansch: Nature 436 (2005) 234.

26) R. J. Jones, K. D. Moll, M. J. Thorpe, and J. Ye: Phys. Rev. Lett. 94 (2005) 193201.

27) D. C. Yost, T. R. Schibli, and Jun Ye: Opt. Lett. 33 (2008) 1099.

28) T. Steinmetz, et al.: Science 321 (2008) 1335.

29) C-H. Li, et al.: Nature 452 (2008) 610.

30) S. Yamazoe, M. Katou, T. Adachi, and T. Kasamatsu: Opt. Lett. 35 (2010) 748.

31) P. Wasylczyk, P. Wnuk, and C. Radzewicz: Opt. Express 17 (2009) 5630.

32) Y. Kobayashi, Y. Nomura, and S. Watanabe: $C L E O / Q E L S$, San Jose, CA, 2010.

33) M. J. Thorpe, et al.: Opt. Express 16 (2008) 2387.

34) B. Bernhardt, A. Ozawa, P. Jacquet, M. Jacquey, Y. Kobayashi, T. Udem, R. Holzwarth, G.Guelachvili, T. W. Hansch, and N. Picque: Nature Photon. 4 (2010) 55.

$$
\text { レーザーワード- }
$$

UVコム (extreme ultraviolet optical frequency comb)

波長領域が極端紫外 (XUV) 領域にある光周波数コ ム、XUVコムは直接レーザー発振器から出力させるこ とはできないため可視や赤外の光周波数コムの波長変換 により生成する。極端紫外領域であるため波長変換とし ては希ガスを非線形媒質として用いた高次高調波発生を
用いる。高繰り返し高強度レーザーが必要となるため フェムト秒レーザーパルス列をエンハンスメント共振器 と呼ばれる外部共振器に閉じ込め, 強度を高めた状態の 共振器内部で波長変換を行う。共振器内部の超短パルス レーザーの平均強度は数 $\mathrm{kW}$ になる。

(小林 洋平) 